\title{
Analysis of the impact of foreign investor trading activity on return, liquidity, and volatility of the Indonesian Stock Market before and during the COVID-19 crisis period
}

\author{
F.R. Nandaru \& B. Wibowo \\ Universitas Indonesia, Indonesia
}

\begin{abstract}
The COVID-19 pandemic caused a decline in the Indonesian stock market performance. This paper analyzes how much of the decline was due to foreign investor trading activity and how much its impact differed prior to the crisis period. Stock market performance is proxied by return, liquidity, and volatility. Meanwhile, foreign investor trading activity is proxied by buying and selling volume, value, and frequency. Trading data for each period were processed through OLS regression with Newey-West's HAC procedure. The results reveal that foreign investor trading activity caused a bi-directional impact on return and liquidity, where the impact on both was greater during the crisis period. Additionally, foreign investor trading activity impacted volatility significantly during the non-crisis period, while an increase in the trading activity increased volatility during the crisis period.
\end{abstract}

\section{INTRODUCTION}

The stock market is an integral part of Indonesia's economic development. Its growth and return potential have attracted not only domestic investors, but also the foreign ones. Foreign investors investing in the Indonesian Stock Exchange (IDX) have grown to a sizable population, carrying out $46 \%$ of the total trades in the second quartile of 2015 (IDX 2019). However, during the COVID-19 crisis, foreign investors became passive traders. Considering the large number of foreign investors, decline in their trading activities may have a significant impact on the IDX performance. This paper analyzes the impact of foreign investor trading activity during the crisis period and its changes prior to the COVID-19 crisis.

Due to the pandemic and regulations such as social distancing and lockdowns from governments worldwide, the financial prospects of businesses all over the world and investor confidence declined. Liu et al. (2020) observed that stock markets worldwide provided negative abnormal returns, particularly those in Asia due to the strong spillover effect. Many studies have analyzed the impact of foreign investor trading activity on the stock market performance during non-crisis and crisis periods. However, the results vary due to the differences in location, period, or types of trading data used. This study is useful, as the results and a more robust understanding of the role of foreign investors in Indonesia during crises can be beneficial to prevent and counteract potential crises that may arise in the future.

\section{LITERATURE REVIEW}

Multiple researchers have conducted studies that are relevant to this study. Vo (2017), Nguyen (2017), and Samarakoon (2009) found that foreign investor trading activity caused a bi-directional impact on the stock market return, while Junior and Eid (2017) showed that the impact doubled during a crisis. Peranginangin et al. (2016); Agudelo (2010); and Liew, Lim, and Goh (2018) 
observed that trading inactivity reduced liquidity, and its impact was greater during a crisis. Choe, Kho, and Stulz (1999) stated that foreign investors generally were unwilling to trade during a crisis, thereby reducing market liquidity substantially. Meanwhile, Umutlu and Shackleton (2015); Che (2018); and Wang (2007) revealed that trading activity increased volatility.

Regarding the crisis period, Rhee and Wang (2009) and Peranginangin (2016) found that foreign investors in Indonesia tend to utilize the buy and hold strategy, sell small stocks, and buy stocks with a large market capitalization to secure a less risky portfolio. Not only that, foreign investors, who were net buyers, became net sellers. Because of this, the trading volume of foreign investors investing in Indonesia fell from $45 \%$ to $18 \%$ of total trades before it rose again after the crisis was over. Richards (2005) and Agarwal et al. (2009) implied that foreign investors in Indonesia were more risk-averse and had a significant impact on the stock market performance during crises, especially on liquidity.

\section{DATA AND METHODOLOGY}

\subsection{Data}

The daily historical price data of IDX from January 2019 to September 2020 were obtained through Thompson Reuters, while the data of foreign investor trading activity were obtained through TICMI. The data were then split into two period categories: normal (before 30 January 2020) and crisis (after 30 January 2020). The normal period contains data for 248 trading days, while the crisis period contains data for 162 trading days.

\subsection{Variables and methodology}

This research assessed the stock market performance using dependent variables, including return, liquidity, and volatility. The stock return was calculated by subtracting the current stock price from the previous day's stock price and dividing it by the previous day's stock price. Furthermore, the liquidity was measured by a high-low spread estimator procedure using the daily highest and lowest price of a stock (Corwin and Schultz 2012). The procedure is illustrated by the following equations:

$$
\begin{aligned}
& S=\frac{2\left(e^{\alpha}-1\right)}{1+e^{\alpha}} \\
& \alpha=\frac{\sqrt{2 \beta}-\sqrt{\beta}}{3-2 \sqrt{2}}-\sqrt{\frac{\gamma}{3-2 \sqrt{2}}} \\
& \beta=\left[\ln \left(\frac{H_{t}}{L_{t}}\right)\right]^{2}+\left[\ln \left(\frac{H_{t+1}}{L_{t+1}}\right)\right]^{2} \\
& \gamma=\left[\ln \left(\frac{\max \left\{H_{t}, H_{t+1}\right\}}{\min \left\{L_{t}, L_{t+1}\right\}}\right)\right]
\end{aligned}
$$

where is the liquidity measure, $H_{t}$ is the highest price at day $t$, and $L_{t}$ is the lowest price at day $t$. In terms of volatility, this study used the average of the 14-day average true range (ATR) and standard deviation. The true range was calculated by taking the greatest difference between the highest and lowest price of the day, the absolute value of the difference between the highest price of the day and the closing price of the previous day, and the absolute value of the difference between the lowest price of the day and the closing price of the previous day. The ATR was then calculated by taking the 14-day average of true range.

The independent variables of this research are buying and selling volume, value, and frequency of foreign investors. Volume is defined by the number of stocks traded. Value is the nominal amount traded, while frequency is the number of transactions that occurred. The variables were then processed through OLS regression with Newey-West's HAC procedure. 


\section{RESULTS AND DISCUSSION}

Table 1. Regression results

\begin{tabular}{llllllllll}
\hline \multicolumn{1}{c}{ Constant } & S_Volume & S_Value & S_Frequency & B_Volume & B_Value & B-Frequency & R-Squared & F-statistic \\
\hline Panel A: Normal Period & & & & & & & & & \\
Return & 0.000649 & $1.52 \mathrm{E}-13$ & $2.29 \mathrm{E}-16$ & $-1.47 \mathrm{E}-07$ & $-3.37 \mathrm{E}-14$ & $1.42 \mathrm{E}-16$ & $1.42 \mathrm{E}-07$ & 0.198 & 0.000000 \\
& $(-0.38)$ & $(-0.33)$ & $(-0.79)$ & $(-6.63)^{* * *}$ & $(-0.20)$ & $(2.85)^{* * *}$ & $(6.67)^{* * *}$ & & \\
Liquidity & -0.205716 & $6.77 \mathrm{E}-12$ & $-5.22 \mathrm{E}-15$ & $-8.63 \mathrm{E}-07$ & $8.73 \mathrm{E}-13$ & $-5.19 \mathrm{E}-16$ & $6.76 \mathrm{E}-07$ & 0.115 & 0.000214 \\
& $(-15.22)^{* * *}$ & $(2.33)^{* *}$ & $(-2.47)^{* *}$ & $(-3.51)^{* * *}$ & $(-0.59)$ & $(-1.17)$ & $(2.90)^{* * *}$ & & \\
Volatility & 0.0006606 & $-1.69 \mathrm{E}-13$ & $1.19 \mathrm{E}-16$ & $3.29 \mathrm{E}-08$ & $-1.69 \mathrm{E}-13$ & $4.65 \mathrm{E}-17$ & $-2.23 \mathrm{E}-08$ & 0.135 & 0.000035 \\
& $(8.40)^{* * *}$ & $(-1.16)$ & $(-0.76)$ & $(3.67)^{* * *}$ & $(-2.63)^{* * *}$ & $(2.36)^{* * *}$ & $(-2.47)^{* *}$ & & \\
Panel B: Crisis period & & & & & & & & & \\
Return & -0.014747 & $9.76 \mathrm{E}-12$ & $-4.38 \mathrm{E}-15$ & $-1.66 \mathrm{E}-07$ & $-6.14 \mathrm{E}-12$ & $2.91 \mathrm{E}-15$ & $3.53 \mathrm{E}-07$ & 0.251 & 0.000032 \\
& $(-1.56)$ & $(3.48)^{* * *}$ & $(-1.43)$ & $(-3.32)^{* * *}$ & $(-1.63)$ & $(-0.89)$ & $(3.34)^{* * *}$ & & \\
Liquidity & -0.157945 & $4.10 \mathrm{E}-11$ & $-4.66 \mathrm{E}-14$ & $-5.21 \mathrm{E}-07$ & $-2.74 \mathrm{E}-11$ & $2.74 \mathrm{E}-14$ & $-7.05 \mathrm{E}-07$ & 0.286 & 0.000000 \\
& $(-5.15)^{* * *}$ & $(2.35)^{* *}$ & $(-2.21)^{* *}$ & $(-1.20)$ & $(-1.41)$ & $(-1.54)$ & $(-1.92)^{*}$ & & \\
Volatility & 0.000898 & $-1.01 \mathrm{E}-12$ & $-1.38 \mathrm{E}-15$ & $1.25 \mathrm{E}-07$ & $1.95 \mathrm{E}-12$ & $-3.34 \mathrm{E}-16$ & $4.96 \mathrm{E}-08$ & 0.159 & 0.000283 \\
& $(-0.26)$ & $(-0.42)$ & $(-.0 .59)$ & $(3.24)^{* * *}$ & $(-1.13)$ & $(-0.21)$ & $(-1.13)$ & & \\
\hline
\end{tabular}

$* * *, * *$, and $*$ indicate statistical significance at the $1 \%, 5 \%$, and $10 \%$ level, respectively

As expected, this study's findings differ from the previous studies' results since the variables studied were different. The findings imply that whether it was buying or selling activity, each characteristic of the said activities, namely, frequency, volume, and value, had different impacts on the stock market performance in different periods. Furthermore, it is also implied that the impact was greater during crises, especially on liquidity, where the impact was six to nine times greater than the impact during the normal period. This highlights the importance of foreign investors in Indonesia during crises.

As stated by Rhee and Wang (2009) and Peranginangin (2016), foreign investors became net sellers and less active in trading during crises. Combined with the implication that foreign investors have a stronger impact during crises, it can be said that foreign investors played an important role in the decline of IDX's performance. This is probably due to the decline in foreign investors' confidence regarding the financial prospect of the Indonesian stock market during the crisis. This is because of the Indonesian government's inability to handle the pandemic or Indonesian businesses' incapability to maintain their operations at a profitable level.

\section{CONCLUSIONS}

Through this research, the impact of foreign investor trading activity on IDX's performance could be understood. In line with previous studies, an increase in trading activity had a bi-directional impact on returns, liquidity, and volatility, while during crises, an increase in trading activity increased volatility. The findings show that each characteristic of trading activities had different impacts on the stock market performance, and the impact was greater during crises.

The decline in foreign investors' confidence played an important part in the IDX's performance during the COVID-19 crisis. To uplift their confidence, the Indonesian government should be able to handle the spread of the virus more efficiently and give financial stimulus to citizens and struggling businesses. Therefore, the level of consumption could be maintained and businesses could still operate. If the government can maintain a healthy business environment, foreign investors' confidence can also be maintained, leading to a better performance of the stock market. Alternatively, they could try to reduce dependence on foreign investors with the increase of the population size and influence of domestic investors. This could be achieved by improving the level of public 
financial literacy. Therefore, the Indonesian government may be able to prevent or at least minimize the impact of crises that may arise in the future.

This study has several limitations that can make the findings to be less than ideal. First of all, the number of observations for the crisis period is limited since the crisis was still ongoing when this study was conducted. For liquidity, Liew, Lim, and Goh (2018) stated that the best proxy is CPQS, which requires bid-ask data. Unfortunately, IDX did not provide such data, so this study had to switch to another proxy. For further research, it will be better if the number of observations during the crisis period is increased. It is recommended to wait until the COVID-19 crisis is declared over, so the impact of foreign investors after the crisis could also be analyzed. The research could also be conducted with domestic investor trading activity to compare and contrast the impact caused by domestic and foreign investors.

\section{REFERENCES}

Agarwal, S., Faircloth, S., Liu, C., and Ghon Rhee, S., 2009. Why do foreign investors underperform domestic investors in trading activities? Evidence from Indonesia. Journal of Financial Markets, 12 (1), 32-53.

Agudelo, D.A., 2010. Friend or Foe? Foreign Investors and the Liquidity of Six Asian Markets. Asia-Pacific Journal of Financial Studies, 39 (3), 261-300.

Che, L., 2018. Investor types and stock return volatility. Journal of Empirical Finance, 47, 139-161.

Choe, H., Kho, B.-C., and Stulz, R.M., 1999. Do foreign investors destabilize stock markets? The Korean experience in 1997. Journal of Financial Economics, 54 (2), 227-264.

Corwin, S.A. and Schultz, P., 2012. A Simple Way to Estimate Bid-Ask Spreads from Daily High and Low Prices. The Journal of Finance, 67 (2), 719-760.

IDX, 2019. IDX Annually Statistic [online]. Available from: https://www.idx.co.id/media/8473/idx_annuallystatistic_2019.pdf.

Junior, W. and Eid, W., 2017. Sophistication and price impact of foreign investors in the Brazilian stock market. Emerging Markets Review.

Liew, P.-X., Lim, K.-P., and Goh, K.-L., 2018. Foreign equity flows: Boon or bane to the liquidity of Malaysian stock market? The North American Journal of Economics and Finance, 45, 161-181.

Liu, H., Manzoor, A., Wang, C., Zhang, L., and Manzoor, Z., 2020. The COVID-19 Outbreak and Affected Countries Stock Markets Response. International Journal of Environmental Research and Public Health, $17,2800$.

Nguyen, T., 2017. The Impact of Foreign Investor Trading Activity on Vietnamese Stock Market. International Journal of Marketing Studies, 9, 109.

Peranginangin, Y., Ali, A., Brockman, P., and Zurbruegg, R., 2016. The impact of foreign trades on emerging market liquidity. Pacific-Basin Finance Journal, 40.

Rhee, S. and Wang, J., 2009. Foreign Institutional Ownership and Stock Market Liquidity: Evidence from Indonesia. Journal of Banking \& Finance, 33, 1312-1324.

Richards, A., 2005. Big Fish in Small Ponds: The Trading Behavior and Price Impact of Foreign Investors in Asian Emerging Equity Markets. The Journal of Financial and Quantitative Analysis, 40 (1), 1-27.

Samarakoon, L.P., 2009. The relation between trades of domestic and foreign investors and stock returns in Sri Lanka. Journal of International Financial Markets, Institutions and Money, 19 (5), 850-861.

Umutlu, M. and Shackleton, M.B., 2015. Stock-return volatility and daily equity trading by investor groups in Korea. Pacific-Basin Finance Journal, 34, 43-70.

Vo, X.V., 2017. Trading of foreign investors and stock returns in an emerging market - Evidence from Vietnam. International Review of Financial Analysis, 52, 88-93.

Wang, J., 2007. Foreign equity trading and emerging market volatility: Evidence from Indonesia and Thailand. Journal of Development Economics, 84 (2), 798-811. 